\title{
Targeting Fibroblast Activation Protein: Radiosynthesis and Preclinical Evaluation of an ${ }^{18}$ F-Labeled FAP Inhibitor
}

\author{
Johannes Toms ${ }^{1}$, Jürgen Kogler ${ }^{1}$, Simone Maschauer ${ }^{1}$, Christoph Daniel ${ }^{2}$, Christian Schmidkonz ${ }^{3}$, Torsten Kuwert ${ }^{3}$, \\ and Olaf Prante ${ }^{1,3}$ \\ ${ }^{I}$ Friedrich-Alexander University Erlangen-Nürnberg (FAU), Department of Nuclear Medicine, Molecular Imaging and \\ Radiochemistry, Translational Research Center, Erlangen, Germany; ${ }^{2}$ Friedrich-Alexander University Erlangen-Nürnberg \\ (FAU), Department of Nephropathology, Erlangen, Germany; and ${ }^{3}$ Friedrich-Alexander University Erlangen-Nürnberg (FAU), \\ Department of Nuclear Medicine, Erlangen, Germany
}

Fibroblast activation protein (FAP) has emerged as an interesting molecular target used in the imaging and therapy of various types of cancers. ${ }^{68} \mathrm{Ga}$-labeled chelator-linked FAP inhibitors (FAPIs) have been successfully applied to PET imaging of various tumor types. To broaden the spectrum of applicable PET tracers for extended imaging studies of FAP-dependent diseases, we herein report the radiosynthesis and preclinical evaluation of an ${ }^{18} \mathrm{~F}$-labeled glycosylated FAPI ([18F]FGIc-FAPI). Methods: An alkyne-bearing precursor was synthesized and subjected to click chemistry-based radiosynthesis of $\left[{ }^{18} \mathrm{~F}\right] \mathrm{FGlc}-\mathrm{FAPI}$ by 2 -step ${ }^{18} \mathrm{~F}$-fluoroglycosylation. FAPexpressing HT1080hFAP cells were used to study competitive binding to FAP, cellular uptake, internalization, and efflux of $\left[{ }^{18} \mathrm{~F}\right]$ FGIc-FAPI in vitro. Biodistribution studies and in vivo small-animal PET studies of $\left[{ }^{18} \mathrm{~F}\right] \mathrm{FGlc}-\mathrm{FAPI}$ compared with $\left[{ }^{68} \mathrm{Ga}\right] \mathrm{Ga}-\mathrm{FAPI}-04$ were conducted in nude mice bearing HT1080hFAP tumors or U87MG xenografts. Results: $\left[{ }^{18} \mathrm{~F}\right] \mathrm{FGIC}-\mathrm{FAPI}$ was synthesized with a $15 \%$ radioactivity yield and a high radiochemical purity of more than $99 \%$. In HT1080hFAP cells, $\left[{ }^{18} \mathrm{~F}\right.$ FGIc-FAPI showed specific uptake, a high internalized fraction, and low cellular efflux. Compared with FAPI-04 (half maximal inhibitory concentration $\left[\mathrm{IC}_{50}\right]=$ $32 \mathrm{nM})$, the glycoconjugate, FGIc-FAPI $\left(\mathrm{IC}_{50}=167 \mathrm{nM}\right)$, showed slightly lower affinity for FAP in vitro, whereas plasma protein binding was higher for $\left[{ }^{18} \mathrm{~F}\right] \mathrm{FGIC}-\mathrm{FAPI}$. Biodistribution studies revealed significant hepatobiliary excretion of $\left[{ }^{18} \mathrm{~F}\right] \mathrm{FGlc}-\mathrm{FAPI}$; however, smallanimal PET studies in HT1080hFAP xenografts showed higher specific tumor uptake of $\left[{ }^{18} \mathrm{~F}\right] \mathrm{FGIC}-\mathrm{FAPI}$ (4.5 percentage injected dose per gram of tissue [\%ID/g]) than of [ $\left.{ }^{8} \mathrm{Ga}\right] \mathrm{Ga}-\mathrm{FAPI}-04(2 \% \mathrm{ID} / \mathrm{g})$. In U87MG tumor-bearing mice, both tracers showed similar tumor uptake, but $\left[{ }^{18} \mathrm{~F}\right] \mathrm{FGlc}-\mathrm{FAPI}$ showed a higher tumor retention. Interestingly, $\left[{ }^{18} \mathrm{~F}\right] \mathrm{FGlc}-\mathrm{FAPI}$ demonstrated high specific uptake in bone structures and joints. Conclusion: $\left[{ }^{18} \mathrm{~F}\right] \mathrm{FGlc}-\mathrm{FAPI}$ is an interesting candidate for translation to the clinic, taking advantage of the longer half-life and physical imaging properties of ${ }^{18} \mathrm{~F}$. The availability of $\left[{ }^{18} \mathrm{~F}\right] \mathrm{FGlC}-\mathrm{FAPI}$ may allow extended PET studies of FAP-related diseases, such as cancer, but also arthritis, heart diseases, or pulmonary fibrosis.

\footnotetext{
Received Feb. 2, 2020; revision accepted Apr. 5, 2020.

For correspondence or reprints contact: Olaf Prante, Department of Nuclear Medicine, Molecular Imaging and Radiochemistry, Friedrich-Alexander University Erlangen-Nürnberg (FAU), Schwabachanlage 12, 91054 Erlangen, Germany.

E-mail: olaf.prante@uk-erlangen.de

Published online Apr. 24, 2020.

COPYRIGHT (C 2020 by the Society of Nuclear Medicine and Molecular Imaging.
}

Key Words: fibroblast activation protein; cancer-associated fibroblasts; ${ }^{18} \mathrm{~F} ;{ }^{18} \mathrm{~F}$-fluoroglycosylation; PET

J Nucl Med 2020; 61:1806-1813

DOI: $10.2967 /$ jnumed.120.242958

$\mathbf{T}$ serine protease with dipeptidyl peptidase and endopeptidase activities (1). The regulation and role of FAP has been studied for almost 3 decades and has gained special attention as a highly expressed marker in the vast majority of epithelial tumors (2), as well as in fibrosis (3) and rheumatoid arthritis (4). More generally, FAP is associated with the pathologic and even nonpathologic remodeling of the extracellular matrix (5). The basal expression of FAP in healthy human tissue is considered very low, whereas in mice detectable levels of FAP expression were shown to be highest in the uterus, pancreas, submaxillary gland, and skin (6). In the case of cancer, FAP is not expressed on malignant tumor cells themselves, but on cancer-associated fibroblasts (CAFs), a nonmalignant cell subtype of the stroma, which is a major part of a tumor's composition (7). However, even though recognized as nonmalignant cells, CAFs are heavily involved in tumor growth, migration, and progression of the disease by communicating with several cell types through the secretion of growth factors and chemokines (8). Not only is the mediating role of CAFs in cancer manifold, but also the cells originate from various sources. Endothelial cells, resident fibroblasts, adipocytes, and bone marrow-derived hematopoietic or mesenchymal stem cells have been described as putative precursors that differentiate into CAFs (9). Although low expression of FAP has been also shown on some CAF precursors, FAP overexpression by CAFs is a key characteristic and is often connected to a bad prognosis and outcomes for respective cancers (10). Several approaches targeting FAP have been made using antibodies $(11,12)$, peptide prodrugs (13), or small molecules (14). However, limited success has been achieved in preclinical studies such that few candidates have entered clinical studies $(15,16)$. The protein structure of FAP was described in 2005 (17), together with the first generation of FAP inhibitors (FAPIs) that showed good affinity but lacked selectivity. Second-generation FAPIs were structurally based on a quinoline amide core coupled to a 2-cyanopyrrolidine moiety (18); these demonstrated nanomolar affinity and selectivity for FAP with only a low affinity to other interfering dipeptidyl peptidases $(19,20)$. 
Recently, the development of PET ligands was successfully achieved by the introduction of a DOTA chelator coupled to an alkyl-piperazine spacer linked to the quinoline core and labeled with ${ }^{68} \mathrm{Ga}$ $(21,22)$. A ${ }^{68} \mathrm{Ga}$-labeled FAPI tracer $\left(\left[{ }^{68} \mathrm{Ga}\right] \mathrm{Ga}-F A P I-04\right.$; Fig. 1) demonstrated high tumor-to-organ ratios and fast elimination in preclinical experiments. Moreover, first-in-human PET studies with $\left[{ }^{68} \mathrm{Ga}\right.$ ]Ga-FAPI-04 revealed the excellent visualization of a broad range of tumors, with high tumor-to-noise ratios and the successful imaging of tumor metastases $(23,24)$. In addition, derivatives of FAPI-04 are under development that may allow radiolabeling with ${ }^{177} \mathrm{Lu}$ for application in endoradiotherapy, provided that the biologic half-life is appropriate for the therapeutic demand (25).

IWe here report an alkyne-bearing version of FAPI-04 and its use as a precursor for the click chemistry-based synthesis of an ${ }^{18} \mathrm{~F}$-labeled FAPI. In previous studies, we demonstrated that the introduction of ${ }^{18} \mathrm{~F}$-labeled glycosyl moieties could positively influence the clearance behavior of a radiotracer (26-28), and the glycosylation of biomolecules has been frequently shown to improve the in vivo stability in blood and allows for the optimization of active drug delivery $(29,30)$. Therefore, herein, we present the radiosynthesis and preclinical evaluation of an ${ }^{18} \mathrm{~F}$-labeled glycosylated FAPI ([ ${ }^{18}$ F]FGlc-FAPI; Fig. 1) as a new ${ }^{18}$ F-fluoroglycosylated FAP ligand. In direct comparison with $\left[{ }^{68} \mathrm{Ga}\right] \mathrm{Ga}-\mathrm{FAPI}-04$, we report biodistribution studies and small-animal PET studies of $\left[{ }^{18} \mathrm{~F}\right] \mathrm{FGlc}-$ FAPI in nude mice xenografts of FAP-positive tumors.

\section{MATERIALS AND METHODS}

\section{General}

The stably FAP-transfected fibrosarcoma cell line HT1080hFAP and the precursor FAPI-04 were kindly provided by Professor Uwe Haberkorn (University Hospital Heidelberg, Germany).

\section{Chemistry}

The syntheses of all nonradioactive compounds, including the reference compound FGlc-FAPI and the radiosyntheses of $\left[{ }^{68} \mathrm{Ga}\right] \mathrm{Ga}-F A P I-04$ and $\left[{ }^{177} \mathrm{Lu}\right] \mathrm{Lu}-\mathrm{FAPI}-04$ are described in detail in the supplemental information supplemental materials are available at http://jnm.snmjournals.org).

\section{Radiosynthesis of $\left[{ }^{18} \mathrm{~F}\right] \mathrm{FGIC}-\mathrm{FAPI}$}

Starting from the tosylate precursor 1, 2,3,4-tri- $O$-acetyl-6-deoxy-6$\left[{ }^{18} \mathrm{~F}\right]$ fluoroglucosyl azide $\left(\left[{ }^{18} \mathrm{~F}\right] 2\right)$ was prepared, isolated, and deacetylated

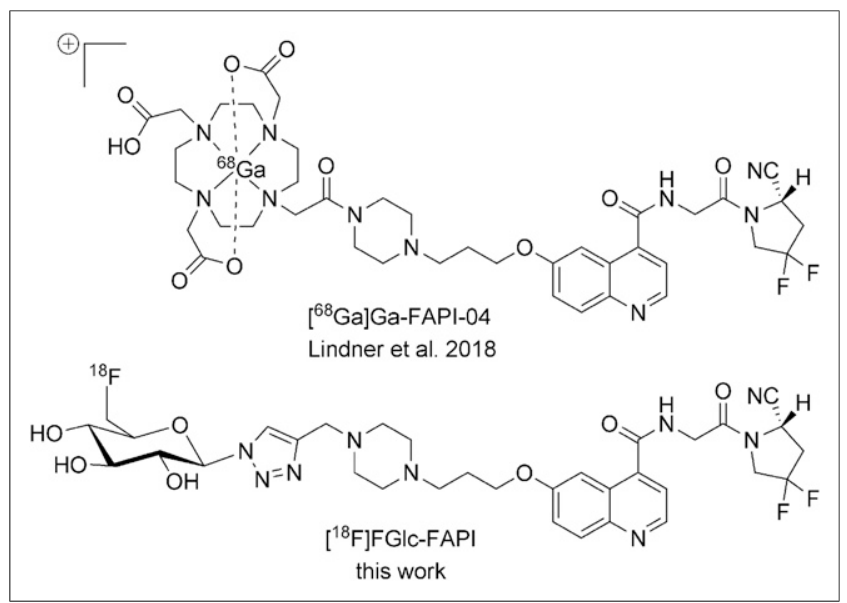

FIGURE 1. Molecular structure of $\left[{ }^{68} \mathrm{Ga}\right] \mathrm{Ga}-\mathrm{FAPI}-04(22)$ and $\left[{ }^{18} \mathrm{~F}\right] \mathrm{FGlc}-$ FAPI (this work). with $\mathrm{NaOH}(270 \mu \mathrm{L}, 60 \mathrm{mM})$ at $60^{\circ} \mathrm{C}$ for $5 \mathrm{~min}$ as described before (27). To the crude product 6-deoxy-6- $\left[{ }^{18} \mathrm{~F}\right]$ fluoroglucosyl azide $\left(\left[{ }^{18} \mathrm{~F}\right] 3\right)$, a mixture of phosphate buffer $(270 \mu \mathrm{L}, 0.5 \mathrm{M}, \mathrm{pH} 8), \mathrm{Cu}(\mathrm{OAc})_{2}$ (20 $\mu \mathrm{L}, 4 \mathrm{mM}$ ), tris(3-hydroxypropyltriazolylmethyl)amine (THPTA; $20 \mu \mathrm{L}, 20 \mathrm{mM})$, sodium ascorbate $(20 \mu \mathrm{L}, 0.1 \mathrm{M})$, and alkyne 11 $(1 \mathrm{mM}, 400 \mu \mathrm{L})$ was added and the reaction was stirred for $15 \mathrm{~min}$ at $60^{\circ} \mathrm{C}$. The radiochemical yield of $\left[{ }^{18} \mathrm{~F}\right]$ FGlc-FAPI was $52 \%-85 \%$ as determined by analytic high-performance liquid chromatography (HPLC) (method 2) from a sample withdrawn from the reaction mixture. Purification of $\left[{ }^{18} \mathrm{~F}\right] \mathrm{FGlc}-\mathrm{FAPI}$ was performed by semipreparative HPLC (method 1, retention time $=10.3 \mathrm{~min}$ ). The product fraction was diluted with water and passed through a RP-18 cartridge (Sep-Pak light C18; Waters). $\left[{ }^{18}\right.$ F]FGlc-FAPI was eluted with ethanol $(2 \mathrm{~mL})$ and after evaporation of the solvent, $\left[{ }^{18} \mathrm{~F}\right] \mathrm{FGlc}-\mathrm{FAPI}$ was formulated with $0.9 \%$ saline. Starting from $\left[{ }^{18}\right.$ F $]$ fluoride $(500-1,000 \mathrm{MBq})$, $\left[{ }^{18} \mathrm{~F}\right]$ FGlc-FAPI was obtained in a radioactivity yield of $30-130 \mathrm{MBq}$ (6\%-15\%, referred to ${ }^{18} \mathrm{~F}$-fluoride) in a total synthesis time of $90-110$ min in specific activities of 30-200 GBq/ $\mu \mathrm{mol}(n=11)$.

\section{Plasma Protein Binding}

The binding of tracers to plasma proteins was determined using a microcolumn separation method. The radiotracer $(1 \mu \mathrm{L}, 100-500 \mathrm{kBq})$ was added to human plasma $(100 \mu \mathrm{L})$ and incubated for $10 \mathrm{~min}$ at $37^{\circ} \mathrm{C}$. The microcolumns (illustra MicroSpin G-50 columns; GE Healthcare) were preconditioned as described by the manufacturer and a sample of the plasma $(50 \mu \mathrm{L})$ was carefully applied to the resin. The columns were placed in an Eppendorf tube and centrifuged (2 min, 2000 $\mathrm{g}$ ). The eluate and the remaining resin were both collected separately and measured using a $\gamma$-counter. The radioactivity that eluted from the resin, representing the plasma protein bound tracer, was calculated as percentage of the total amount of radioactivity in the sample. The experiment was performed twice each in triplicate.

\section{In Vitro Studies}

The determination of $\log \mathrm{D}_{7.4}$ (performed in triplicate in two independent experiments), tracer stability in human serum (analyzed by radio-HPLC using method $5\left[\left[{ }^{18} \mathrm{~F}\right] \mathrm{FGlc}-\mathrm{FAPI}\right]$ or method $4\left[\left[{ }^{68} \mathrm{Ga}\right]\right.$ Ga-FAPI-04]), cellular uptake (performed in quadruplicate for each time point and calculated as percentage injected dose [\% ID] $] 10^{6}$ cells), internalization, and efflux (each performed in quadruplicate in 2 independent experiments) were performed as previously reported (28). HT1080hFAP cells were cultivated in Dulbecco modified Eagle medium containing $10 \%$ fetal calf serum at $37^{\circ} \mathrm{C}$ and a $\mathrm{CO}_{2}$ content of $5 \%$ and seeded to 48 -well plates until reaching $80 \%-100 \%$ confluence.

\section{Competitive FAP Binding Assay}

Competitive binding experiments were performed in 96-well plates using $\left[{ }^{177} \mathrm{Lu}\right] \mathrm{Lu}-\mathrm{FAPI}-04$ as radioligand. For this, HT1080hFAP cells $(100,000$ cells/well) were seeded $24 \mathrm{~h}$ before the experiment and washed with medium once before application of the nonradioactive test substances FGlc-FAPI, FAPI alkyne 11, Ga-FAPI-04, and DOTAFAPI-04 in concentrations ranging from $1 \mathrm{nM}$ to $5 \mu \mathrm{M}$ in $90 \mu \mathrm{L}$ of medium. For FGlc-FAPI, FAPI alkyne 11, and DOTA-FAPI-04 the concentrations were achieved by weighting and dissolving of the substance, for Ga-FAPI-04 by HPLC measurement using a calibration curve. $\left[{ }^{177} \mathrm{Lu}\right] \mathrm{Lu}-\mathrm{FAPI}-04$ was subsequently added (in $10 \mu \mathrm{L}$ of medium, $\sim 0.1 \mathrm{MBq} /$ well) and incubated for $60 \mathrm{~min}$ at $37^{\circ} \mathrm{C}$. After setting the plate on ice, the cells were washed with medium and cold phosphate-buffered saline. Finally, the cells were lysed with $1 \mathrm{M} \mathrm{NaOH}$ and counted. Half maximal inhibitory concentration $\left(\mathrm{IC}_{50}\right)$ values were calculated using Prism 6.0 Software (GraphPad, One-Site Fit $\log \mathrm{IC}_{50}$ ) from the raw data (in cpm). The experiments were performed in triplicate, and 2-3 independent experiments were conducted. 


\section{DPP4 Activity Assay}

FAPI-04, FAPI alkyne 11, and FGlc-FAPI were incubated in concentrations between $1 \mathrm{nM}$ and $1 \mathrm{mM}$ together with $125 \mathrm{mU}$ purified DPP4 (Sigma Aldrich) in $130 \mu \mathrm{L}$ of HEPES buffer $(\mathrm{pH}$ 7.6) for 10 min at $37^{\circ} \mathrm{C}$ in 96 -well microtiter plates. Purified DPP4 with activity between 3.9 and $125 \mathrm{mU}$ was used as standards. After addition of Gly-Pro-pNA (4-nitroaniline, Sigma Aldrich) as DPP4 substrate (100 $\mu \mathrm{L}$ of $1 \mathrm{mM}$ solution) kinetics of enzymatic pNA release (25 cycles in $20 \mathrm{~min}$ ) were monitored at $405 \mathrm{~nm}$ in a microplate ELISAreader (Synergy II, BioTek Instruments Inc.). IC $_{50}$ values were calculated using Prism 6.0 software (GraphPad, One-Site Fit $\left.\log \mathrm{IC}_{50}\right)$. All measurements were carried out in duplicate.

\section{Tumor Xenotransplantation}

All animal experiments were approved by the local animal protection authorities (Government of Central Franconia, Germany, no. 55.2 25322-279) and performed in accordance with the relevant European Union guidelines and regulations. Female athymic nude mice (CD1-Foxn1/nu, homozygous) were obtained from Charles River Laboratories (Germany) at 4 wk of age and were kept under standard conditions (12 h light/dark) with nude mice food and water available ad libitum for at least $5 \mathrm{wk}$. Viable cells were harvested, suspended in phosphatebuffered saline/Matrigel (Corning, Inc.) $(1: 1,100 \mu \mathrm{L})$, and injected subcutaneously in the left $\left(5 \times 10^{6} \mathrm{HT} 1080 \mathrm{hFAP}\right.$ cells/mouse or $2 \times$ $10^{6}$ U87MG cells/mouse) back of the mice. The body weight and diameter of each tumor were determined and documented every 2-3 days. Two to four weeks after inoculation, the mice, now weighing about $30 \mathrm{~g}$ and bearing tumors of $6.5-15 \mathrm{~mm}$ (for HT1080hFAP) and $2.5-7 \mathrm{~mm}$ (for U87MG) in diameter, were used for biodistribution and small-animal PET studies.

\section{Biodistribution}

The tumor-bearing mice were anesthetized with $\mathrm{O}_{2}$ /isoflurane $(2 \%-$ $3 \%$ isoflurane, $\left.1.2 \mathrm{~L} / \mathrm{min} \mathrm{O}_{2}\right)$ and laid on a heating pad $\left(37^{\circ} \mathrm{C}\right)$. About $1-2 \mathrm{MBq}(100 \mu \mathrm{L})$ of $\left[{ }^{18} \mathrm{~F}\right]$ FGlc-FAPI (and $30 \mathrm{nmol} / \mathrm{mouse}$ of FAPI alkyne $\mathbf{1 1}$ as blocking substance) were injected via the tail vein. The mice were then transferred to a cage and allowed to recover from anesthesia. The mice were euthanized by cervical dislocation under deep isoflurane anesthesia at $30 \mathrm{~min}(n=2), 60 \mathrm{~min}$ $(n=2), 60 \mathrm{~min}$ (coinjection of 11, $n=2)$, and $90 \mathrm{~min}(n=2)$ after injection, and samples from tissues and blood were removed and weighed and radioactivity counted in the $\gamma$-counter. The results are presented as percentage injected dose per gram of tissue $(\% \mathrm{ID} / \mathrm{g})$, and tumor-to-organ ratios were calculated thereof. The values are given as mean value $\pm \mathrm{SD}$.

\section{Small-Animal PET Imaging}

Mice bearing xenografted HT1080hFAP or U87MG tumors were laid on a heating pad $\left(37^{\circ} \mathrm{C}\right)$ and were anesthetized using $\mathrm{O}_{2} /$ isoflurane (2\%-3\% isoflurane, $\left.1.2 \mathrm{~L} / \mathrm{min} \mathrm{O}_{2}\right)$. A venous access was laid into the tail vein of the animals, and the cannula was fixed by an instant adhesive on the tail. The mice were transferred to an Inveon microPET scanner (Siemens Healthcare), tempered by a heating pad $\left(37^{\circ} \mathrm{C}\right)$. A dynamic PET scan was started from 0 to 60 min after injection of 2-5 MBq of $\left[{ }^{18} \mathrm{~F}\right]$ FGlc-FAPI $(n=2-3)$ or $3-5 \mathrm{MBq}$ of $\left[{ }^{68} \mathrm{Ga}\right] \mathrm{Ga}-\mathrm{FAPI}-04$ $(n=2-5)$ in $100 \mu \mathrm{L}$ of isotonic saline solution. For 3 mice, a 15 minstatic scan was acquired at $120 \mathrm{~min}$ after tracer injection. The blocking experiments were performed by coinjection of $\left[{ }^{18} \mathrm{~F}\right] \mathrm{FGlc}-\mathrm{FAPI}$ and alkyne 11 (30 or $100 \mathrm{nmol} / \mathrm{animal}, n=3$ ). After iterative maximum a posteriori image reconstruction of the decay- and attenuation-corrected images, regions of interest were defined using the software PMOD (PMOD Technologies LLC). The mean radioactivity concentration within the regions of interest was converted to $\% \mathrm{ID} / \mathrm{g}$ and provided as mean value $\pm \mathrm{SD}$.

\section{RESULTS}

\section{Chemistry and Radiochemistry}

Inspired by recently published results on $\left[{ }^{68} \mathrm{Ga}\right] \mathrm{Ga}-\mathrm{FAPI}-04$, we synthesized the alkyne-bearing derivative $\mathbf{1 1}$ as a derivative of FAPI-04. This can lead to chemoselective copper(I)-catalyzed alkyne azide cycloaddition (CuAAC) reactions, such as a wide variety of ${ }^{18}$ F-click chemistry-based labeling methods (31). The alkyne precursor 11 is composed of a dipeptide analog synthesized according to Jansen et al. (20), a quinoline unit, and a piperazinealkyl linker, which was synthesized by a modified procedure following Lindner et al. (22). The alkyne 11 was obtained with an overall yield of $13 \%$ over 6 reaction steps (Supplemental Fig. 1). Applying chemoselective $\mathrm{CuAAC}$ reaction with 11 and 6-deoxy6 -fluoro- $\beta$-glucosyl azide (3 (27)), we obtained glycoconjugate FGlc-FAPI with a yield of $66 \%$ and a purity of $95 \%$ as a FAPI test compound and reference compound of the ${ }^{18} \mathrm{~F}$-labeled analog.

On the basis of our previous experience in the development of ${ }^{18} \mathrm{~F}$-labeled glycoconjugates as PET imaging agents $(27,28,32)$, the radiosynthesis of $\left[{ }^{18} \mathrm{~F}\right] \mathrm{FGlc}-\mathrm{FAPI}$ was started from precursor 1 (27) for ${ }^{18} \mathrm{~F}$-substitution, followed by ${ }^{18} \mathrm{~F}$-fluoroglycosylation of 11 (400 nmol) under optimized reaction conditions (Fig. 2). The complete 2-step radiosynthesis was performed in a maximum of 90-110 min, providing a $\left[{ }^{18} \mathrm{~F}\right] \mathrm{FGlc}-\mathrm{FAPI}$ formulated tracer with a radioactivity yield of $15 \%$, a radiochemical purity of more than $99 \%$, and a molar activity of 30-200 GBq/ $\mu$ mol (Supplemental Figs. 2-4).

\section{In Vitro Evaluation of $\left[{ }^{18} \mathrm{~F}\right] \mathrm{FGIC}-\mathrm{FAPI}$}

Although $\left[{ }^{68} \mathrm{Ga}\right] \mathrm{Ga}-\mathrm{FAPI}-04$ showed high hydrophilicity $\left(\log \mathrm{D}_{7.4}=\right.$ $-2.41 \pm 0.28),\left[{ }^{18} \mathrm{~F}\right] \mathrm{FGlc}-\mathrm{FAPI}$ was less polar $\left(\log \mathrm{D}_{7.4}=-0.99 \pm\right.$ $0.03)$. Both tracers showed high stability in human serum after incubation for $55 \mathrm{~min}$ of more than $99 \%$ for $\left[{ }^{18} \mathrm{~F}\right] \mathrm{FGlc}-\mathrm{FAPI}$ and $93 \%$ for $\left[{ }^{68} \mathrm{Ga}\right] \mathrm{Ga}-\mathrm{FAPI}-04$. Binding to human blood plasma proteins was determined for $\left[{ }^{18} \mathrm{~F}\right]$ FGlc-FAPI $(45 \% \pm 6 \%, n=$ $6)$ and was significantly higher than for $\left[{ }^{68} \mathrm{Ga}\right] \mathrm{Ga}-\mathrm{FAPI}-04(10 \% \pm 3 \%$, $n=6)$.

To determine whether the introduction of the alkyne moiety and glycosylation of $\left[{ }^{18} \mathrm{~F}\right]$ FGlc-FAPI had any influence on FAP binding, we performed competition binding experiments with

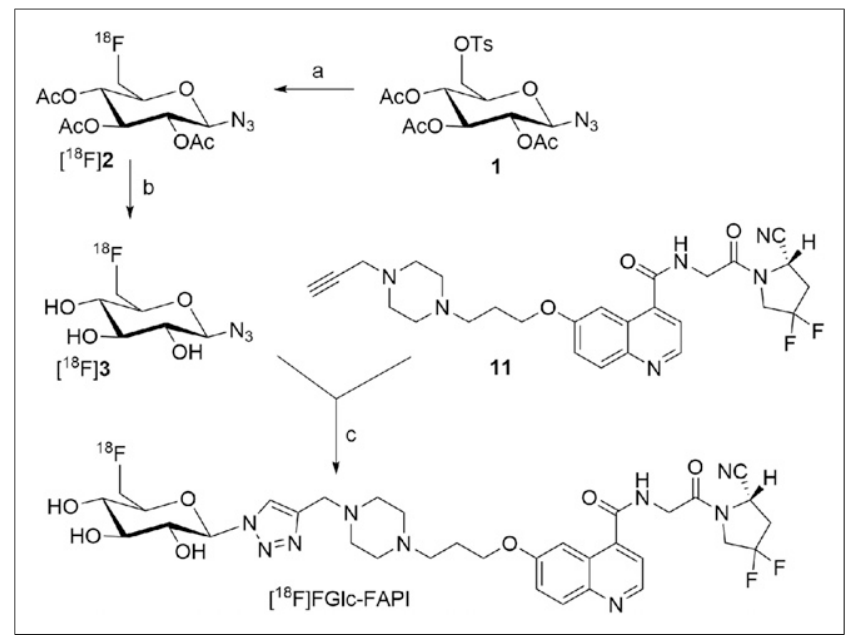

FIGURE 2. ${ }^{18} \mathrm{~F}$-fluoroglycosylation of FAPI alkyne 11. (a) [ $\left.{ }^{18} \mathrm{~F}\right]$ fluoride, $\mathrm{K}_{222}, \mathrm{~K}_{2} \mathrm{CO}_{3}, \mathrm{KH}_{2} \mathrm{PO}_{4}$, acetonitrile, $85^{\circ} \mathrm{C}, 10 \mathrm{~min}$. (b) $\mathrm{NaOH}, 60^{\circ} \mathrm{C}, 5 \mathrm{~min}$ (27). (c) $\mathrm{Cu}(\mathrm{OAc})_{2}$, THPTA, sodium ascorbate, phosphate buffer $\mathrm{pH} 8$, $11,60^{\circ} \mathrm{C}, 15 \mathrm{~min}$. 
$\left[{ }^{177} \mathrm{Lu}\right] \mathrm{Lu}-\mathrm{FAPI}-04$ as a radioligand in HT1080hFAP cells (Fig. 3A). The test compounds FGlc-FAPI, alkyne 11, FAPI-04, and GaFAPI-04 showed $\mathrm{IC}_{50}$ values in a range from double- to triple-digit nanomolar concentrations (Table 1). Due to differences in the assay setup, the $\mathrm{IC}_{50}$ values were in general higher than values reported in the literature (22). All 4 FAPI derivatives led to the displacement of $\left[{ }^{177} \mathrm{Lu}\right] \mathrm{Lu}-\mathrm{FAPI}-04$ of about $75 \%-95 \%$, whereas DOTA derivatives showed a 3- to 5-fold-higher affinity for FAP compared with alkyne 11 and FGlc-FAPI. We also determined the binding to the structurally related peptidase dipeptidyl peptidase 4 (DPP4, CD26), which is highly expressed on blood cells and memory $\mathrm{T}$ cells and, in its soluble form, is present in blood plasma. In direct comparison to FAPI-04, the glycoconjugate FGlc-FAPI and FAPI-alkyne showed comparable $\mathrm{IC}_{50}$ values in the micromolar range, confirming the binding selectivity of FGlc-FAPI for FAP (Table 1, Supplemental Fig. 5).
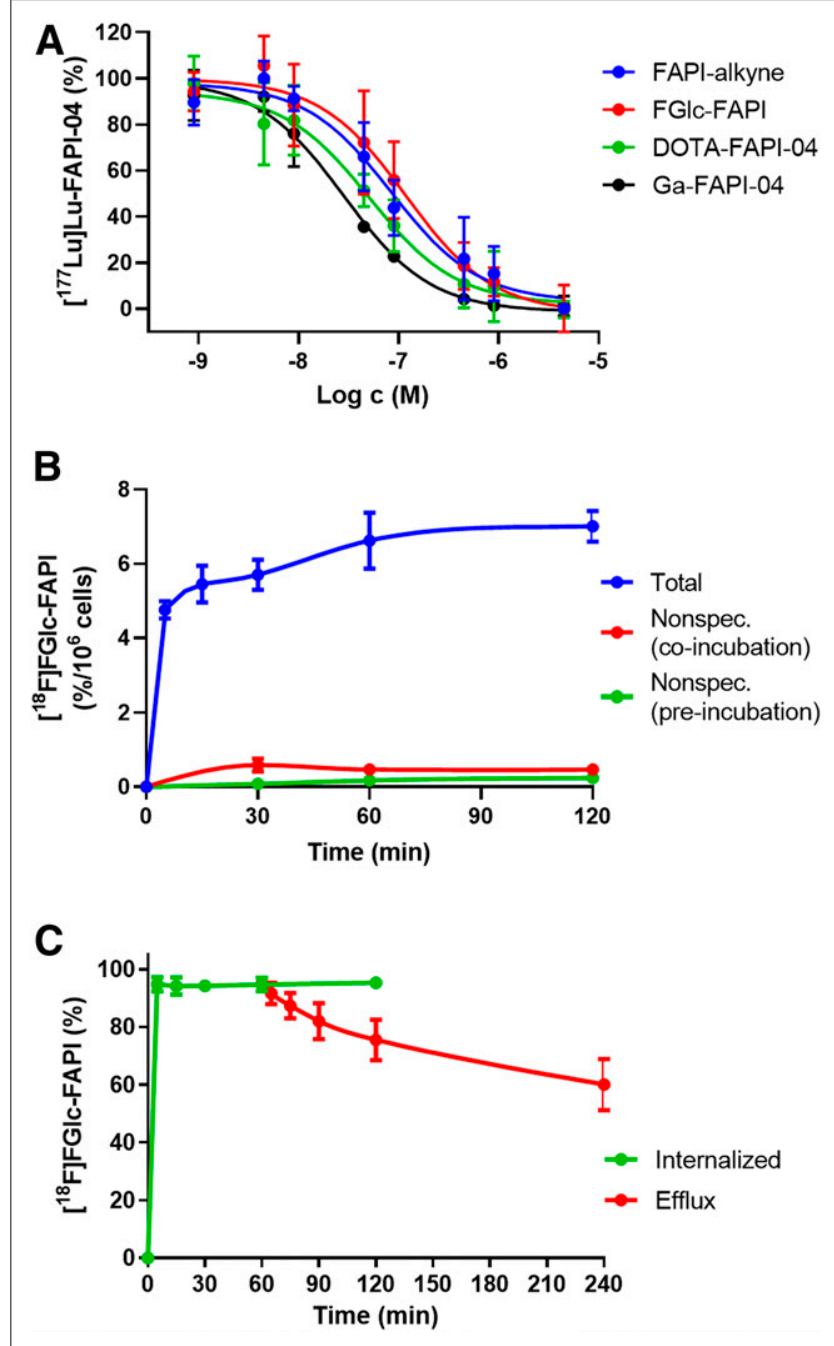

FIGURE 3. (A) Competitive binding in HT1080hFAP cells of 4 reference compounds against [177Lu]Lu-FAPI-04 $(n=6-9)$. (B) Tracer uptake of $\left[{ }^{18} \mathrm{~F}\right] \mathrm{FGlc}-\mathrm{FAPI}$ in HT1080hFAP cells, with and without blocking using FAPI alkyne 11 as a competitor $(n=4)$. (C) Internalization of [ $\left.{ }^{18} \mathrm{~F}\right] \mathrm{FGlc}-$ FAPI in HT1080hFAP cells and efflux of $\left[{ }^{18} \mathrm{~F}\right] \mathrm{FGlc}-\mathrm{FAPI}$ out of HT1080FAP cells after $1 \mathrm{~h}$ incubation and exchange by fresh medium. Each data point represents mean $\pm \operatorname{SD}(n=8)$.
TABLE 1

$\mathrm{IC}_{50}$ Values as Determined by Radioligand Displacement Studies for FAP (Using ${ }^{177}$ Lu-FAPI-04) and by Inhibition of DPP4 Enzyme Activity

\begin{tabular}{lcc}
\hline \multicolumn{1}{c}{ Compound } & $\begin{array}{c}\mathrm{IC}_{50} \text { (FAP) MW } \pm \\
\mathrm{SD}(n=3)\end{array}$ & $\begin{array}{c}\mathrm{IC}_{50}(\mathrm{DPP} 4) \mathrm{MW} \pm \\
\mathrm{SD}(n=2)\end{array}$ \\
\hline FAPI-alkyne (11) & $109 \pm 60 \mathrm{nM}$ & $9.5 \mu \mathrm{M}$ \\
FGlc-FAPI & $167 \pm 110 \mathrm{nM}$ & $26.6 \mu \mathrm{M}$ \\
FAPI-04 & $49 \pm 22 \mathrm{nM}$ & $7.9 \mu \mathrm{M}$ \\
Ga-FAPI-04 & $32 \pm 7 \mathrm{nM}^{*}$ & Not determined \\
& & \\
${ }^{*} n=2$. & & \\
\end{tabular}

$\left[{ }^{18} \mathrm{~F}\right]$ FGlc-FAPI showed specific uptake in HT1080hFAP cells of $6.6 \% \pm 0.8 \%$ after $60 \mathrm{~min}$ of incubation, which could be significantly blocked by the addition of alkyne $\mathbf{1 1}$ to between $3 \%$ and $7 \%$ (Fig. 3B). Additionally, FAP-negative MCF-7 cells did not show any significant uptake of $\left[{ }^{18} \mathrm{~F}\right] \mathrm{FGlc}-\mathrm{FAPI}$, suggesting specific FAPmediated uptake of $\left[{ }^{18} \mathrm{~F}\right] \mathrm{FGlc}-\mathrm{FAPI}$ in HT1080hFAP cells (Supplemental Fig. 6). $\left[{ }^{18} \mathrm{~F}\right]$ FGlc-FAPI showed a fast cellular uptake $(>4 \%$ after $5 \mathrm{~min}$, Fig. 3B) with a rapid and high internalization rate in HT1080hFAP cells (95\% after 5-120 min; Fig. 3C), confirming results for ${ }^{177} \mathrm{Lu}$-labeled FAPI derivatives reported by Lindner et al. (22). After $60 \mathrm{~min}$ of incubation with $\left[{ }^{18} \mathrm{~F}\right]$ FGlc-FAPI, $75 \%$ of the tracer was still internalized, demonstrating the low cellular efflux rate of $\left[{ }^{18} \mathrm{~F}\right]$ FGlc-FAPI in vitro (Fig. $3 \mathrm{C}$ ).

\section{Biodistribution of $\left[{ }^{18} \mathrm{~F}\right] \mathrm{FGIC}-\mathrm{FAPI}$}

Biodistribution studies of $\left[{ }^{18} \mathrm{~F}\right] \mathrm{FGlc}-\mathrm{FAPI}$ in HT1080hFAP tumor-bearing mice revealed tumor uptake of $1.6 \%-2.0 \% \mathrm{ID} / \mathrm{g}(n=$ 2, Table 2, Supplemental Fig. 7A), with high retention from 30 to $90 \mathrm{~min}$ after injection. The tracer uptake was shown to be specific by the coinjection of $\left[{ }^{18} \mathrm{~F}\right]$ FGlc-FAPI together with $\mathbf{1 1}(30 \mathrm{nmol} /$ mouse), demonstrating diminished tumor uptake by $56 \%$ at $60 \mathrm{~min}$ after injection $(0.9 \pm 0.2 \% \mathrm{ID} / \mathrm{g}, n=2$, Table 2 , Supplemental Fig. 7B). Notably, partial necrosis of the tumors was observed, such that the tumor uptake of $\left[{ }^{18} \mathrm{~F}\right]$ FGlc-FAPI was heterogeneous and moderate. Biodistribution studies of $\left[{ }^{18} \mathrm{~F}\right] \mathrm{FGlc}-\mathrm{FAPI}$ also demonstrated pronounced uptake in the liver and intestine, suggesting a hepatobiliary excretion pathway for $\left[{ }^{18} \mathrm{~F}\right]$ FGlc-FAPI. The observed uptake in the bones (femur) was constant over time, similar to the uptake in tumors, and could be blocked by approximately $80 \%$ (3.4 $\% \mathrm{ID} / \mathrm{g}$ vs. $0.6 \% \mathrm{ID} / \mathrm{g}, n=2$, Table 2, Supplemental Fig. 7B), suggesting specific binding to bone marrow. Similarly, the concentration of $\left[{ }^{18} \mathrm{~F}\right] \mathrm{FGlc}-\mathrm{FAPI}$ in the blood was diminished under blocking conditions (Table 2, Supplemental Fig. 7B).

\section{Small-Animal PET Imaging}

For a proof-of-concept study and an assessment of the tracer performance of $\left[{ }^{18} \mathrm{~F}\right] \mathrm{FGlc}-\mathrm{FAPI}$ in comparison to $\left[{ }^{68} \mathrm{Ga}\right] \mathrm{Ga}$-FAPI04, small-animal PET studies using HT1080hFAP xenografts were conducted. Dynamic measurements over the course of $60 \mathrm{~min}$ after injection revealed fast biodistribution and specific uptake in HT1080hFAP tumors in vivo, both for $\left[{ }^{18} \mathrm{~F}\right]$ FGlc-FAPI and for $\left[{ }^{68} \mathrm{Ga}\right] \mathrm{Ga}-\mathrm{FAPI}-04$ (Fig. 4). Tumor uptake of $\left[{ }^{18} \mathrm{~F}\right]$ FGlc-FAPI was limited to intact tumor tissue, as necrotic areas inside the tumor did not show any significant tracer uptake (Fig. 4A). At an early time point after tracer injection (10 min after injection), $\left[{ }^{18} \mathrm{~F}\right] \mathrm{FGlc}-\mathrm{FAPI}$ reached 
TABLE 2

Biodistribution Data of $\left[{ }^{18} \mathrm{~F}\right] \mathrm{FGlc}-\mathrm{FAPI}$ in HT1080hFAP Xenografts for 30, 60, and 90 Minutes After Injection and of $\left[{ }^{18} \mathrm{~F}\right]$ FGlc-FAPI Coinjected with Competitor 11 (30 nmol/mouse, Blocking) for 60 Minutes After Injection

\begin{tabular}{lcccc}
\hline \multicolumn{1}{c}{ Tissue } & $30 \mathrm{~min}$ & $60 \mathrm{~min}$ & $90 \mathrm{~min}$ & $60-\mathrm{min}$ blocking \\
\hline Blood & $2.3 \pm 0.9$ & $1.1 \pm 0.6$ & $0.7 \pm 0.2$ & $0.2 \pm 0.1$ \\
\hline Lung & $1.5 \pm 0.2$ & $0.8 \pm 0.3$ & $0.5 \pm 0.2$ & $0.3 \pm 0.1$ \\
\hline Liver & $4.0 \pm 1.4$ & $2.2 \pm 0.1$ & $1.7 \pm 0.2$ & $2.9 \pm 1.2$ \\
\hline Kidney & $1.7 \pm 0.1$ & $1.5 \pm 0.3$ & $1.0 \pm 0.2$ & $1.4 \pm 0.3$ \\
\hline Heart & $1.3 \pm 0.5$ & $0.7 \pm 0.5$ & $0.4 \pm 0.2$ & $0.1 \pm 0.1$ \\
\hline Spleen & $1.0 \pm 0.5$ & $0.5 \pm 0.1$ & $0.3 \pm 0.1$ & $0.4 \pm 0.3$ \\
Brain & $0.13 \pm 0.02$ & $0.05 \pm 0.02$ & $0.07 \pm 0.03$ & $0.02 \pm 0.01$ \\
\hline Muscle & $1.5 \pm 0.3$ & $1.2 \pm 0.5$ & $0.9 \pm 0.2$ & $0.2 \pm 0.1$ \\
\hline Femur & $3.2 \pm 0.5$ & $3.4 \pm 0.6$ & $2.6 \pm 0.5$ & $0.6 \pm 0.8$ \\
\hline HT1080hFAP Tumor & $1.6 \pm 0.4$ & $2.0 \pm 0.5$ & $5.2 \pm 6.1$ & $0.9 \pm 0.2$ \\
\hline Intestine & $6.1 \pm 4.4$ & $6.4 \pm 6.0$ & $8.0 \pm 9.9$
\end{tabular}

Data are mean $\pm \operatorname{SD}(n=2)$.

a tumor uptake of $4.6 \% \mathrm{ID} / \mathrm{g}$ and showed retention in the tumor over the time period of the PET scan (Fig. 4C). In comparison, $\left[{ }^{68} \mathrm{Ga}\right] \mathrm{Ga}-$ FAPI-04 showed a lower tumor uptake of $2.1 \% \mathrm{ID} / \mathrm{g}$ (Fig. 4B, D), though homogenous tracer distribution was noted in the tumors.

As an alternative tumor model for FAP-transfected HT1080 cancer cell xenografts, we generated U87MG xenografts for PET imaging studies. In vitro, U87MG cells lack FAP expression, however, U87MG xenograft tumors are FAP-positive in vivo, which is ascribed to the recruitment and activation of mouse fibroblasts (CAF) (33). In these more homogeneous growing tumors, a similarly high uptake of $\left[{ }^{18} \mathrm{~F}\right]$ FGlc-FAPI and $\left[{ }^{68} \mathrm{Ga}\right] \mathrm{Ga}-\mathrm{FAPI}-04$ was observed $(\sim 7 \% \mathrm{ID} / \mathrm{g}$, Figs. 5A and 5B). Interestingly, $\left[{ }^{68} \mathrm{Ga}\right] \mathrm{Ga}-\mathrm{FAPI}-04$ reached maximum uptake at 15 min after injection, which subsequently slightly decreased. However, the tumor uptake of $\left[{ }^{18} \mathrm{~F}\right] \mathrm{FGlc}-\mathrm{FAPI}$ slightly but constantly increased, beginning from an initial rapid uptake phase at $10 \mathrm{~min}$ after injection to the end of the total scan time of $60 \mathrm{~min}$ (Fig. 5B). The high tumor retention of $\left[{ }^{18} \mathrm{~F}\right]$ FGlc-FAPI has been additionally proven by PET scans at 120-130 min after injection (Supplemental Fig. 8).

Unexpectedly, a high and specific uptake of $\left[{ }^{18} \mathrm{~F}\right]$ FGlc-FAPI was also detected in bone structures, for example, in the joints, spine, skull, and shoulders (Fig. 5C, Supplemental Fig. 9), as demonstrated by uptake of around $6 \% \mathrm{ID} / \mathrm{g}$ in the knee joints (Figs. 5C and 5D). However, $\left[{ }^{68} \mathrm{Ga}\right] \mathrm{Ga}-$ FAPI-04 accumulated in the knee joints to a lower extent $(2.8 \pm 1.4 \% \mathrm{ID} / \mathrm{g})$. Blocking studies confirmed the specific uptake of $\left[{ }^{18} \mathrm{~F}\right] \mathrm{FGlc}-\mathrm{FAPI}$ in the knee joint region ([ $\left.{ }^{18} \mathrm{~F}\right]$ FGlc-FAPI: $6.0 \pm 2.5 \% \mathrm{ID} / \mathrm{g}$ vs. blocking: $0.36 \pm 0.06 \% \mathrm{ID} / \mathrm{g} ; n=4-6$, all values for $55 \mathrm{~min}$ after injection, Fig. 5D). Both tracers showed fast blood clearance (Fig. 5E). However, contrary to the low concentration of $\left[{ }^{68} \mathrm{Ga}\right] \mathrm{Ga}-\mathrm{FAPI}-04$ in the blood at $55 \mathrm{~min}$ after injection, $\left[{ }^{18} \mathrm{~F}\right] \mathrm{FGlc}-$ FAPI showed a higher residual blood concentration than $\left[{ }^{68} \mathrm{Ga}\right] \mathrm{Ga}-\mathrm{FAPI}-04$ (Fig. 5E, insert).
FIGURE 4. Representative small-animal PET images and time-activity-curves of HT1080hFAP xenografts using $\left[{ }^{18} \mathrm{~F}\right] \mathrm{FGIC}-\mathrm{FAPI}(\mathrm{A}, \mathrm{C})$ and $\left[{ }^{68} \mathrm{Ga}\right] \mathrm{Ga}-\mathrm{FAPI}-04(\mathrm{~B}, \mathrm{D})$ and respective blocking experiments with competitor 11 ( $30 \mathrm{nmol} /$ mouse).

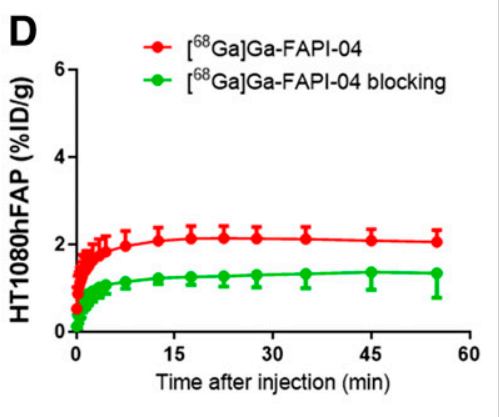




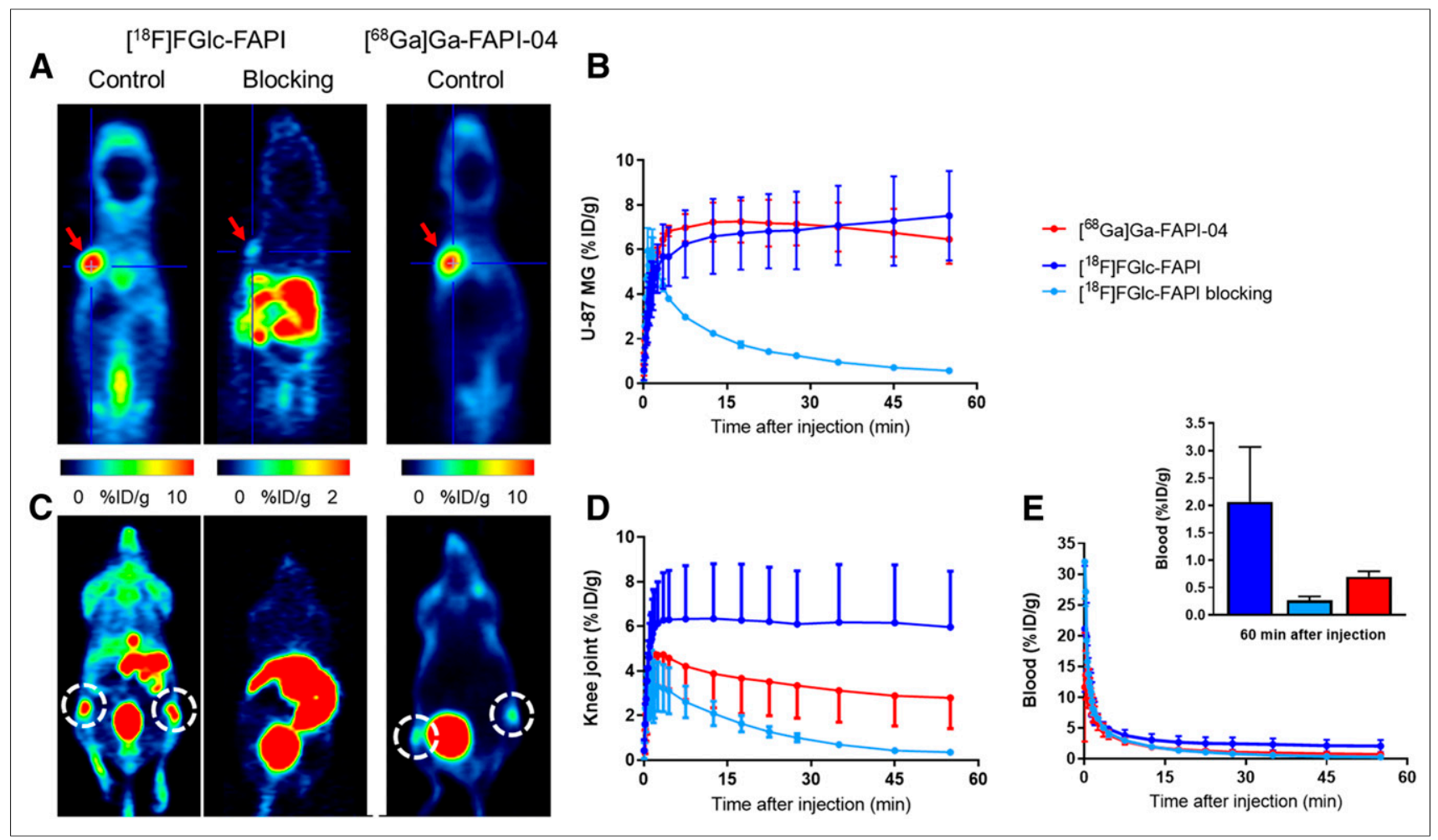

FIGURE 5. Representative small-animal PET images and time-activity curves of U87MG xenografts using $\left[{ }^{18} \mathrm{~F}\right] \mathrm{FGlC}-\mathrm{FAPI}\left(\mathrm{A}, \mathrm{C}\right.$ left side), $\left[{ }^{18} \mathrm{~F}\right] \mathrm{FGlC}-$ FAPI together with competitor 11 (100 nmol/mouse) (A, C middle), and $\left[{ }^{68} \mathrm{Ga}\right] \mathrm{Ga}-\mathrm{FAPI}-04$ (A, C right side). (A and B) Projection of the U87MG tumor (red arrows) and time-activity curves of U87MG tumor uptake in \%ID/g. (C-E) Projection of knee joints (dashed circles) and time-activity curves for blood represented by integration of radioactivity in heart.

\section{DISCUSSION}

To take advantage of the favorable properties of ${ }^{18} \mathrm{~F}$, we envisaged the design and synthesis of the alkyne-bearing FAPI derivative 11, rendering click chemistry-based ${ }^{18} \mathrm{~F}$-fluoroglycosylation feasible for the radiosynthesis of a new ${ }^{18} \mathrm{~F}$-labeled FAPI glycoconjugate, $\left[{ }^{18} \mathrm{~F}\right] \mathrm{FGlc}$-FAPI. ${ }^{18} \mathrm{~F}$-fluoroglycosylation is well established in our laboratory and has proven its potential in the development of new PET radiopharmaceuticals $(26,34)$. We have optimized an automated synthesis module for ${ }^{18} \mathrm{~F}$-glycosylation, successfully running the radiosynthesis of 4 different ${ }^{18} \mathrm{~F}$-glycoconjugates in a reliable manner, with a robust radioactivity yield of 15\%-20\% (35). Currently, the module is used in a clean room laboratory for the good manufacturing practice-compliant manufacture of ${ }^{18} \mathrm{~F}$-glycoconjugates, such as $\left[{ }^{18} \mathrm{~F}\right] \mathrm{FGlc}-\mathrm{FAPI}$, to facilitate firstin-humans PET imaging studies.

In vitro, cellular uptake in FAP-transfected human fibrosarcoma cells, ligand binding, internalization, and efflux of $\left[{ }^{18} \mathrm{~F}\right] \mathrm{FGlc}-\mathrm{FAPI}$ were similar to those of $\left[{ }^{68} \mathrm{Ga}\right] \mathrm{Ga}-\mathrm{FAPI}-04$, as expected. However, FAP binding affinity was 5 times lower for $\left[{ }^{18} \mathrm{~F}\right]$ FGlc-FAPI, but still within the 3-digit nanomolar range. Also, plasma protein binding and lipophilicity were distinctly higher for $\left[{ }^{18} \mathrm{~F}\right] \mathrm{FGlc}-\mathrm{FAPI}$ than $\left[{ }^{68} \mathrm{Ga}\right] \mathrm{Ga}-\mathrm{FAPI}-04$. The replacement of the hydrophilic gallium complex with a triazolyl glucosyl moiety (Fig. 1) induced lipophilicity in the molecule under physiologic conditions $(\mathrm{pH} 7.4)$ and increased the $\log \mathrm{D}_{7.4}$ value from -2.4 to -1.0 . This increase in lipophilicity is in agreement with higher binding to plasma proteins. In fact, the difference in blood-plasma binding between $\left[{ }^{18} \mathrm{~F}\right] \mathrm{FGlc}-$ FAPI $(45 \%)$ and $\left[{ }^{68} \mathrm{Ga}\right] \mathrm{Ga}-\mathrm{FAPI}-04(10 \%)$ was the most striking difference of all measured in vitro results. The most abundant plasma protein, serum albumin, binds a large diversity of small organic molecules to shield their lipophilic character, thereby increasing their solubility in plasma and prolonging the circulating half-life, as shown by our in vivo results for $\left[{ }^{18} \mathrm{~F}\right]$ FGlc-FAPI compared with $\left[{ }^{68} \mathrm{Ga}\right] \mathrm{Ga}$-FAPI-04.

In agreement to increased plasma protein binding and lipophilicity, biodistribution studies of $\left[{ }^{18} \mathrm{~F}\right] \mathrm{FGlc}-\mathrm{FAPI}$ in mice revealed that the excretion of $\left[{ }^{18} \mathrm{~F}\right] \mathrm{FGlc}-\mathrm{FAPI}$ was through the kidneys as well as the hepatobiliary pathway, which was comparable to the recently reported biodistribution of $\left[{ }^{64} \mathrm{Cu}\right] \mathrm{Cu}-\mathrm{FAPI}-04$ (36). For comparison, $\left[{ }^{68} \mathrm{Ga}\right] \mathrm{Ga}-\mathrm{FAPI}-04$ is almost exclusively excreted by the kidneys and bladder (22). Clearly, a pronounced nonspecific uptake of [ $\left.{ }^{18} \mathrm{~F}\right] \mathrm{FGlc}-$ FAPI in the liver and intestine may be a problem for the detection of abdominal FAP-positive lesions in tumor patients. Therefore, firstin-humans studies are necessary to clarify whether the excretion of $\left[{ }^{18} \mathrm{~F}\right]$ FGlc-FAPI in human is similar to that in mice or whether predominant renal elimination occurs in humans.

Our results of small-animal PET studies using HT1080hFAP xenografts demonstrated that $\left[{ }^{18} \mathrm{~F}\right]$ FGlc-FAPI specifically bound to the tumor, revealing equal or even higher tumor uptake values compared with $\left[{ }^{68} \mathrm{Ga}\right] \mathrm{Ga}$-FAPI-04. However, PET images with higher tumor-to-background ratios were achieved with $\left[{ }^{68} \mathrm{Ga}\right]$ Ga-FAPI-04 due to the lower plasma protein binding and, thereby, faster blood clearance of $\left[{ }^{68} \mathrm{Ga}\right] \mathrm{Ga}-\mathrm{FAPI}-04$. In addition, we performed small-animal PET studies in U87MG tumor-bearing mice, confirming previous studies that, in vivo, U87MG cells recruit activated FAP-positive fibroblasts or, by communicating with CAFs, express FAP (33); such cells were previously used for preclinical imaging including PET with $\left[{ }^{68} \mathrm{Ga}\right] \mathrm{Ga}-\mathrm{FAPI}-04(33,37)$. 
The most eye-catching observation using $\left[{ }^{18} \mathrm{~F}\right]$ FGlc-FAPI for PET imaging was its high uptake in bone structures in U87MG tumor-bearing mice. In comparison with $\left[{ }^{68} \mathrm{Ga}\right] \mathrm{Ga}-\mathrm{FAPI}-04$, the accumulation of $\left[{ }^{18} \mathrm{~F}\right] \mathrm{FGlc}-\mathrm{FAPI}$ in the spine, femur, skull, knees, and shoulders was unexpectedly high. Blocking experiments revealed that $\left[{ }^{18} \mathrm{~F}\right]$ FGlc-FAPI uptake was significantly diminished by coinjection of 11, suggesting specific binding of $\left[{ }^{18} \mathrm{~F}\right] \mathrm{FGlc}-$ FAPI in these regions. In vivo defluorination of $\left[{ }^{18} \mathrm{~F}\right] \mathrm{FGlc}-\mathrm{FAPI}$ was excluded by the blocking experiments, and was, to date, never observed for ${ }^{18} \mathrm{~F}$-fluoroglycosylated compounds.

Our in vitro and in vivo results demonstrated higher plasma protein binding of $\left[{ }^{18} \mathrm{~F}\right]$ FGlc-FAPI compared with $\left[{ }^{68} \mathrm{Ga}\right] \mathrm{Ga}-\mathrm{FAPI}-04$, negligible binding to DPP4-positive blood cells, and a prolonged circulation time in blood for $\left[{ }^{18} \mathrm{~F}\right] \mathrm{FGlc}-\mathrm{FAPI}$. These may be the main reasons for the continuously slightly increasing tumor uptake over time (Fig. $5 \mathrm{~B}$ ), but also for the higher uptake of $\left[{ }^{18} \mathrm{~F}\right] \mathrm{FGlc}-\mathrm{FAPI}$ in the knee joints and in bone structures compared with $\left[{ }^{68} \mathrm{Ga}\right] \mathrm{Ga}-\mathrm{FAPI}-04$.

Tran et al. have reported FAP expression of freshly isolated osteogenic cells of nonhematopoietic origin, including multipotent bone marrow stromal cells (BMSCs) (38). The authors found that FAP-reactive $\mathrm{T}$ cells induced severe cachexia and dose-limiting bone toxicity in mice, which appeared to be the result of targeting of FAP-expressing multipotent BMSCs. Therefore, the in vivo accumulation pattern of $\left[{ }^{18} \mathrm{~F}\right]$ FGlc-FAPI may be ascribed to binding to the bone marrow in vivo. Moreover, it has been shown that BMSCs are capable of directed migration toward various tumor types (39), and BMSCs are a source of circulating stem cells that are recruited from the blood into peripheral solid organs in times of tissue remodeling (40). In the U87MG tumor-bearing nude mice model, such circulating murine BMSCs are potential precursor cells of CAFs that are recruited by stroma-building U87MG xenografts (9). Therefore, it is tempting to speculate that $\left[{ }^{18} \mathrm{~F}\right] \mathrm{FGlc}-\mathrm{FAPI}$ is capable of binding to FAP-positive BMSCs and circulating BMSCs, besides binding to FAP-positive CAFs in the tumor tissue. However, a significant role of the binding of $\left[{ }^{18} \mathrm{~F}\right] \mathrm{FGlc}-\mathrm{FAPI}$ to plasma proteins or most abundant proteins in the murine synovial fluid of the knee joints cannot be ruled out. Although preliminary in vitro experiments did not show significant binding to serum albumin, other shared proteins in plasma or synovial fluid, such as several immunoglobulins (41), could bind and trap $\left[{ }^{18} \mathrm{~F}\right]$ FGlc-FAPI. $\left[{ }^{68} \mathrm{Ga}\right] \mathrm{Ga}-$ FAPI-04 also accumulated in bone structures, however, to a much lower extent than $\left[{ }^{18} \mathrm{~F}\right]$ FGlc-FAPI. A reason for this may be the extremely fast and not-adhesive clearance properties of $\left[{ }^{68} \mathrm{Ga}\right] \mathrm{Ga}-$ FAPI-04. The higher specific uptake of $\left[{ }^{18} \mathrm{~F}\right]$ FGlc-FAPI by bone structures compared with $\left[{ }^{68} \mathrm{Ga}\right] \mathrm{Ga}-\mathrm{FAPI}-04$ may be beneficial in monitoring FAP-dependent bone tissue remodeling in diseases such as rheumatoid arthritis by PET.

\section{CONCLUSION}

The glycoconjugate FAPI $\left[{ }^{18} \mathrm{~F}\right]$ FGlc-FAPI showed suitable in vitro and in vivo properties for the tumor imaging of FAP expression in mice, but slower in vivo clearance properties than $\left[{ }^{68} \mathrm{Ga}\right]$ Ga-FAPI-04. Although hepatobiliary clearance of $\left[{ }^{18} \mathrm{~F}\right] \mathrm{FGlc}-\mathrm{FAPI}$ in mice could be a disadvantage for successful clinical translation, the high uptake of $\left[{ }^{18} \mathrm{~F}\right] \mathrm{FGlc}-\mathrm{FAPI}$ in murine bone structures may be an interesting property of this tracer. The glycoconjugate, $\left[{ }^{18} \mathrm{~F}\right]$ FGlc-FAPI, is a viable alternative ${ }^{18} \mathrm{~F}$-labeled FAPI and a promising candidate for translation to the clinic for first-in-humans studies on FAP-dependent bone tissue remodeling in diseases such as rheumatoid arthritis by PET.

\section{DISCLOSURE}

This work was financially supported by the Emerging Fields Initiative (EFI) of the Friedrich-Alexander University ErlangenNürnberg (FAU) (grant 3_Nat_01, "Chemistry in live cells") and by the German Research Foundation (DFG, MA 4295/2-1). No other potential conflict of interest relevant to this article was reported.

\section{ACKNOWLEDGMENTS}

We gratefully thank Dr. Annette Altmann and Prof. Uwe Haberkorn (University Hospital Heidelberg and DKFZ, Heidelberg, Germany) for kindly providing the FAP-transfected HT1080 cell line and FAPI-04. Additional acknowledgments go to Mr. Stefan Söllner, Mr. Manuel Geisthoff, and Mrs. Ulrike Ittstein for excellent technical assistance as well as to Mr. Jan Hellmann, Mrs. Anke Seitz, and Prof. Peter Gmeiner (Chair of Pharmaceutical Chemistry, FAU) for excellent collaboration and help in chemical analyses.

\section{KEY POINTS}

QUESTION: Is an ${ }^{18} \mathrm{~F}$-labeled glycoconjugate inhibitor targeting FAP an effective PET tracer for the imaging of FAP expression?

PERTINENT FINDINGS: This preclinical study showed that [ $\left.{ }^{18} \mathrm{~F}\right] \mathrm{FGIC}-$ FAPI had suitable in vitro and in vivo properties for the imaging of FAP-expressing tumors and is therefore a viable alternative ${ }^{18} \mathrm{~F}$-labeled FAPI.

IMPLICATIONS FOR PATIENT CARE: The glycoconjugate, $\left[{ }^{18} \mathrm{~F}\right] \mathrm{FGlC}-\mathrm{FAPI}$, is a viable alternative ${ }^{18} \mathrm{~F}$-labeled FAPI and a promising candidate for translation to the clinic for the first-inhumans imaging of FAP expression in FAP-related diseases such as rheumatoid arthritis by PET.

\section{REFERENCES}

1. Park JE, Lenter MC, Zimmermann RN, Garin-Chesa P, Old LJ, Rettig WJ. Fibroblast activation protein, a dual specificity serine protease expressed in reactive human tumor stromal fibroblasts. J Biol Chem. 1999;274:36505-36512.

2. Garin-Chesa P, Old LJ, Rettig WJ. Cell surface glycoprotein of reactive stromal fibroblasts as a potential antibody target in human epithelial cancers. Proc Natl Acad Sci USA. 1990;87:7235-7239.

3. Acharya PS, Zukas A, Chandan V, Katzenstein A-LA, Puré E. Fibroblast activation protein: a serine protease expressed at the remodeling interface in idiopathic pulmonary fibrosis. Hum Pathol. 2006;37:352-360.

4. Bauer S, Jendro MC, Wadle A, et al. Fibroblast activation protein is expressed by rheumatoid myofibroblast-like synoviocytes. Arthritis Res Ther. 2006;8: R171.

5. Jacob M, Chang L, Pure E. Fibroblast activation protein in remodeling tissues. Curr Mol Med. 2012;12:1220-1243.

6. Keane FM, Yao T-W, Seelk S, et al. Quantitation of fibroblast activation protein (FAP)-specific protease activity in mouse, baboon and human fluids and organs. FEBS Open Bio. 2014;4:43-54

7. Kalluri R. The biology and function of fibroblasts in cancer. Nat Rev Cancer. 2016;16:582-598.

8. Kalluri R, Zeisberg M. Fibroblasts in cancer. Nat Rev Cancer. 2006;6:392401.

9. Shiga K, Hara M, Nagasaki T, Sato T, Takahashi H, Takeyama H. Cancer-associated fibroblasts: their characteristics and their roles in tumor growth. Cancers (Basel). 2015;7:2443-2458.

10. Cohen SJ, Alpaugh RK, Palazzo I, et al. Fibroblast activation protein and its relationship to clinical outcome in pancreatic adenocarcinoma. Pancreas. 2008;37: $154-158$.

11. Welt S, Divgi CR, Scott AM, et al. Antibody targeting in metastatic colon cancer: a phase I study of monoclonal antibody F19 against a cell-surface protein of reactive tumor stromal fibroblasts. J Clin Oncol. 1994;12:1193-1203. 
12. Mersmann M, Schmidt A, Rippmann JF, et al. Human antibody derivatives against the fibroblast activation protein for tumor stroma targeting of carcinomas. Int J Cancer. 2001;92:240-248.

13. LeBeau AM, Brennen WN, Aggarwal S, Denmeade SR. Targeting the cancer stroma with a fibroblast activation protein-activated promelittin protoxin. Mol Cancer Ther. 2009;8:1378-1386.

14. Ryabtsova O, Jansen K, Van Goethem S, et al. Acylated Gly-(2-cyano) pyrrolidines as inhibitors of fibroblast activation protein (FAP) and the issue of FAP/prolyl oligopeptidase (PREP)-selectivity. Bioorg Med Chem Lett. 2012;22:3412-3417.

15. Eager RM, Cunningham CC, Senzer NN, et al. Phase II assessment of talabostat and cisplatin in second-line stage IV melanoma. BMC Cancer. 2009;9:263.

16. Scott AM, Wiseman G, Welt S, et al. A Phase I dose-escalation study of sibrotuzumab in patients with advanced or metastatic fibroblast activation proteinpositive cancer. Clin Cancer Res. 2003;9:1639-1647.

17. Aertgeerts K, Levin I, Shi L, et al. Structural and kinetic analysis of the substrate specificity of human fibroblast activation protein $\alpha$. J Biol Chem. 2005;280: 19441-19444.

18. Tsai T-Y, Yeh T-K, Chen X, et al. Substituted 4-carboxymethylpyroglutamic acid diamides as potent and selective inhibitors of fibroblast activation protein. $\mathrm{J} \mathrm{Med}$ Chem. 2010;53:6572-6583.

19. Jansen K, Heirbaut L, Cheng JD, et al. Selective inhibitors of fibroblast activation protein (FAP) with a (4-quinolinoyl)-glycyl-2-cyanopyrrolidine scaffold. ACS Med Chem Lett. 2013;4:491-496.

20. Jansen K, Heirbaut L, Verkerk R, et al. Extended structure-activity relationship and pharmacokinetic investigation of (4-quinolinoyl) glycyl-2-cyanopyrrolidine inhibitors of fibroblast activation protein (FAP). J Med Chem. 2014;57:3053-3074.

21. Loktev A, Lindner T, Mier W, et al. A tumor-imaging method targeting cancerassociated fibroblasts. J Nucl Med. 2018;59:1423-1429.

22. Lindner T, Loktev A, Altmann A, et al. Development of quinoline-based theranostic ligands for the targeting of fibroblast activation protein. J Nucl Med. 2018; 59:1415-1422.

23. Giesel FL, Kratochwil C, Lindner T, et al. ${ }^{68} \mathrm{Ga}$-FAPI PET/CT: biodistribution and preliminary dosimetry estimate of 2 DOTA-containing FAP-targeting agents in patients with various cancers. J Nucl Med. 2019;60:386-392.

24. Kratochwil C, Flechsig P, Lindner T, et al. ${ }^{68}$ Ga-FAPI PET/CT: tracer uptake in 28 different kinds of cancer. $J$ Nucl Med. 2019;60:801-805.

25. Loktev A, Lindner T, Burger E-M, et al. Development of novel FAP-targeted radiotracers with improved tumor retention. J Nucl Med. 2019;60:1421-1429.

26. Maschauer S, Einsiedel J, Haubner R, et al. Labeling and glycosylation of peptides using click chemistry: a general approach to ${ }^{18} \mathrm{~F}$-glycopeptides as effective imaging probes for positron emission tomography. Angew Chem Int Ed Engl. 2010;49: 976-979.

27. Maschauer S, Haubner R, Kuwert T, Prante O. ${ }^{18} \mathrm{~F}-$-Glyco-RGD peptides for PET imaging of integrin expression: efficient radiosynthesis by click chemistry and modulation of biodistribution by glycosylation. Mol Pharm. 2014;11:505-515.

28. Potemkin R, Strauch B, Kuwert T, Prante O, Maschauer S. Development of ${ }^{18} \mathrm{~F}-$ fluoroglycosylated PSMA-ligands with improved renal clearance behavior. Mol Pharm. 2020;17:933-943.

29. Davis BG, Robinson MA. Drug delivery systems based on sugar-macromolecule conjugates. Curr Opin Drug Discov Devel. 2002;5:279-288.

30. Moradi SV, Hussein WM, Varamini P, Simerska P, Toth I. Glycosylation, an effective synthetic strategy to improve the bioavailability of therapeutic peptides. Chem Sci. 2016;7:2492-2500.

31. Mirfeizi L, Campbell-Verduyn L, Dierckx RA, Feringa BL, Elsinga PH. Application of click chemistry for PET. Curr Org Chem. 2013;17:2108-2118.

32. Maschauer S, Ott JJ, Bernhardt G, Kuwert T, Keller M, Prante O. ${ }^{18}$ F-labelled triazolyl-linked argininamides targeting the neuropeptide $\mathrm{Y} \mathrm{Y}_{1} \mathrm{R}$ for PET imaging of mammary carcinoma. Sci Rep. 2019;9:12990.

33. Röhrich M, Loktev A, Wefers AK, et al. IDH-wildtype glioblastomas and grade III/IV IDH-mutant gliomas show elevated tracer uptake in fibroblast activation protein-specific PET/CT. Eur J Nucl Med Mol Imaging. 2019;46:2569-2580.

34. Maschauer S, Prante O. Sweetening pharmaceutical radiochemistry by ${ }^{18} \mathrm{~F}$-fluoroglycosylation: a short review. BioMed Res Int. 2014;2014:214748.

35. Ott JJ. Selective neuropeptide and opioid receptor radioligands for imaging studies in vivo by positron emission tomography (PET), $\mathrm{PhD}$ thesis, FAU Erlangen-Nürnberg; 2018.

36. Watabe T, Liu Y, Kaneda-Nakashima K, et al. Theranostics targeting fibroblast activation protein in the tumor stroma: ${ }^{64} \mathrm{Cu}$ - and ${ }^{225} \mathrm{Ac}$-labeled FAPI-04 in pancreatic cancer xenograft mouse models. J Nucl Med. 2020;61:563-569.

37. Li J, Chen K, Liu H, et al. Activatable near-infrared fluorescent probe for in vivo imaging of fibroblast activation protein-alpha. Bioconjug Chem. 2012;23:1704-1711.

38. Tran E, Chinnasamy D, Yu Z, et al. Immune targeting of fibroblast activation protein triggers recognition of multipotent bone marrow stromal cells and cachexia. J Exp Med. 2013;210:1125-1135.

39. Hamada H, Kobune M, Nakamura K, et al. Mesenchymal stem cells (MSC) as therapeutic cytoreagents for gene therapy. Cancer Sci. 2005;96:149-156.

40. Kaplan RN, Psaila B, Lyden D. Niche-to-niche migration of bone-marrow-derived cells. Trends Mol Med. 2007;13:72-81.

41. Bennike T, Ayturk U, Haslauer CM, et al. A normative study of the synovial fluid proteome from healthy porcine knee joints. J Proteome Res. 2014;13:4377-4387. 